Buletin Peternakan Tropis

Bulletin of Tropical Animal Science

Doi: https://doi.org/10.31186/bpt.2.2.76-82
Bul. Pet. Trop. 2(2): 76-82, 2021

e-ISSN: $2722-0788$

p-ISSN: $2722-1733$

\title{
Pengaruh Pemberian Tepung Daun Sirsak (Annona muricata L.) Fermentasi Aspergillus niger terhadap Deposisi Lemak Broiler
}

\section{(Effect of Soursop Leaf Flour (Annona muricata L.) Fermented by Aspergillus niger on Broiler Fat Deposition)}

\author{
Ilham Hutriansyah, Urip Santoso ${ }^{1 *}$, Nurmeiliasari ${ }^{1}$ \\ ${ }^{1}$ Jurusan Peternakan, Fakultas Pertanian, Universitas Bengkulu, Jalan Raya WR Supratman, Kadang Limun, Kota \\ Bengkulu \\ * Penulis Korespondensi (santoso@unib.ac.id)
}

Dikirim (received): 24 Agustus 2021; dinyatakan diterima (accepted): 31 Oktober 2021; terbit (published): 15 November 2021. Artikel ini dipublikasi secara daring pada https://ejournal.unib.ac.id/index.php/buletin_pt/index

\begin{abstract}
This study aimed to evaluate the effect of soursop leaf flour fermented with Aspergillus niger on fat deposition of broiler chickens. This research was carried out from December 12, 2020 to January 18, 2021, located in the Commercial Zone of Animal Laboratory, Department of Animal Science and Animal Science Laboratory, Faculty of Agriculture, Bengkulu University. The research design used was Completely Randomized Design. One hundred and sixty broiler chickens aged 14 days were distributed into 5 treatment groups as follows: $\mathrm{PO}=$ The use of $0 \%$ fermented soursop leaves in the ration; $\mathrm{P} 1=$ The use of $1 \%$ fermented soursop leaves in the ration; $P 2=$ The use of $3 \%$ fermented soursop leaves in the ration; P3 $=$ The use of $5 \%$ fermented soursop leaves in the ration; P4= The use of $7 \%$ fermented soursop leaves in the ration. The results showed that the administration of soursop leaf flour fermented with Aspergillus niger had no significant effect $(P<0.05)$ on abdominal fat, sartorial fat, neck fat, gizzard fat, proventriculus fat and fatty liver score. In conclusion, fermented soursop leaves was not able to reduce fat deposition in broiler chickens.
\end{abstract}

Key words: fermented soursop leaves, Aspergillus niger, fat deposition, broiler

\section{ABSTRAK}

Penelitian ini bertujuan untuk mengevaluasi pengaruh pemberian tepung daun sirsak yang difermentasi dengan Aspergillus niger terhadap deposisi lemak ayam broiler. Penelitian ini telah dilaksanakan pada tanggal 12 Desember 2020 sampai 18 Januari 2021, berlokasi di Commercial Zone of Animal Laboratory, Jurusan Peternakan dan Laboratorium Peternakan Fakultas Pertanian Universitas Bengkulu. Rancangan yang digunakan adalah Rancangan Acak Lengkap. Seratus enam puluh ayam broiler umur 14 hari didistribusikan ke dalam 5 kelompok perlakuan sebagai berikut: $\mathrm{PO}=$ Penggunaan $0 \%$ daun sirsak fermentasi dalam ransum; $\mathrm{P} 1=$ Penggunaan $1 \%$ daun sirsak fermentasi dalam ransum ; $\mathrm{P} 2=$ Penggunaan $3 \%$ daun sirsak fermentasi dalam ransum; $\mathrm{P} 3=$ Penggunaan $5 \%$ daun sirsak fermentasi dalam ransum; P4= Penggunaan 7\% daun sirsak fermentasi dalam ransum. Hasil penelitian menunjukkan bahwa pemberian tepung daun sirsak yang difermentasi dengan Aspergillus niger berpengaruh tidak nyata $(P<0,05)$ terhadap lemak abdomen, lemak sartorial, lemak leher, lemak gizzard, lemak proventrikulus dan fatty liver score, Dapat disimpulkan bahwa pemberian tepung daun sirsak yang difermentasi dengan Aspergillus niger tidak mampu menurunkan deposisi lemak pada ayam broiler.

Kata kunci: daun sirsak fermentasi, Aspergillus niger, deposisi lemak, broiler 


\section{PENDAHULUAN}

Dewasa ini, ayam broiler mengandung lemak yang tinggi sebagai akibat dari hasil seleksi secara intensif. Hasil seleksi ini juga menyebabkan peningkatan kadar lemak dalam karkas sampai mencapai $18 \%$ dan peningkatan deposisi lemak terutama di bagian abdomen. Jadi, masalah tersebut menjadi perhatian khusus bagi para konsumen dan produsen ternak. Kadar lemak dalam karkas dapat diprediksi melalui deposisi lemak di bagian abdomen. Terdapat korelasi positif antara deposisi lemak di bagian abdomen dengan kadar lemak karkas. Tingginya deposisi lemak.

Salah satu cara menurunkan deposisi lemak pada broiler antara lain dengan menambahkan feed supplement. Salah satu tanaman herbal yang diduga dapat menurunkan kadar lemak pada broiler sirsak (Annona muricata L.). Menurut Suranto (2011) daun sirsak mengandung senyawa flavonoid, tannin, fitosterol, fenol, kalsium oksalat, alkaloid, senyawa acetogenins, dan steroida. Flavonoid mempunyai sifat menurunkan deposisi lemak (Bao et al., 2016). Kim et al. (2011) alkaloid dapat menurunkan deposisi lemak dengan memperkecil ukuran sel lemak. Aranaz et al. (2020) melaporkan bahwa senyawa fenol menurunkan kadar lemak dengan cara mempengaruhi lipogenesis dan lipolisis.

Pemanfaatan daun sirsak sebagai feed supplement terkendala oleh serat kasar yang tinggi. Menurut Mait et al (2019) serat kasar merupakan senyawa karbohidrat yang sulit dicerna oleh ternak monogastrik, namun berfungsi untuk mengatur kerja usus, mempercepat laju digesta dan memacu perkembangan organ pencernaan. Menurut Rasyaf (2002) kebutuhan serat kasar untuk broiler sebesar 3-5\%.. Hasil penelitian Hidanah et al. (2009) menyatakan bahwa fermentasi pada tepung limbah tempe dengan menggunakan Aspergillus niger dan Lactobacillus Sp (106-108/cc) masing-masing sebanyak $0,5 \%$ dan $3 \%$ terbukti dapat meningkatkan protein kasar yang semula $12 \%$ menjadi $15 \%$, menurunkan kadar serat kasar dari $44 \%$ menjadi $40 \%$, sedangkan kadar abu tetap pada kisaran $3 \%$.

Menurut Yusak (2004) Aspergillus niger merupakan mikroba yang memiliki kemampuan yang tinggi untuk menghasilkan enzim. Maryanti et al. (2010) menambahkan Aspergillus niger dibandingkan kapang lainnya dapat menghasilkan enzim selulase khususnya ß- glukosidase dalam jumlah tinggi dan memiliki pertumbuhan yang relatif mudah diatur serta tidak menghasilkan mikotoksin sehingga tidak membahayakan ketika diberikan kepada broiler. Hasil penelitian Murwandhono et al. (2006) memfermentasi kulit ubi kayu dengan Aspergillus niger dapat menaikkan kadar protein kasar, lemak kasar, dan kadar abu tepung kulit ubi kayu dan menurunkan serat kasarnya. Kemudian hasil penelitian tersebut dikuatkan oleh Mahendra (2016) yang menyebutkan bahwa Aspergillus niger diketahui dapat menghasilkan enzim pendegradasi serat. Hal ini terjadi karena selama fermentasi, kapang Aspergillus niger menggunakan zat gizi untuk pertumbuhannya dan aktivitas enzimnya dapat meningkatkan kelarutan protein. Mairizal (2009) menambahkan bahwa fermentasi menggunakan Aspergillus niger mampu menurunkan kadar lemak yaitu dengan memanfaatkannya sebagai sumber energi dan menghasilkan enzim yang dapat meningkatkan protein.

Penelitian ini bertujuan untuk mengevaluasi pengaruh pemberian tepung daun sirsak yang difermentasi dengan Aspergillus niger terhadap deposisi lemak broiler. Penggunaan tepung daun sirsak yang difermentasi dengan Aspergillus niger diduga dapat menurunkan deposisi lemak broiler

\section{BAHAN DAN METODE}

Waktu dan Tempat

Penelitian ini telah dilaksanakan pada tanggal 12 Desember 2020 - 18 Januari 2021 di Commercial Zone of Animal Laboratory 
(CZAL) dan Laboratorium Peternakan Jurusan Peternakan Fakultas Pertanian Universitas Bengkulu.

\section{Pembuatan Tepung Daun Sirsak Fermentasi}

Penelitian ini menggunakan daun sirsak yang difermentasi menggunakan kapang Aspergillus niger. Pembuatan tepung daun sirsak dilakukan dengan cara daun sirsak dikeringkan selama 3 hari di bawah sinar matahari. Selanjutnya daun sirsak yang telah kering digiling menjadi tepung. Tepung daun sirsak dikukus selama \pm 30 menit setelah air mendidih. Kemudian tepung didinginkan dan setelah dingin ditaburi dengan Aspergillus niger. Sebanyak 15 gram kultur Aspergillus niger ke dicampurkan ke dalam $1 \mathrm{~kg}$ tepung daun sirsak. Tepung daun sirsak yang sudah diberi Aspergillus niger dimasukkan ke dalam plastik kedap udara dan kemudian dipadatkan, selanjutnya difermentasi selama 4 hari pada suhu ruang. Hasil fermentasi selanjutnya dikeringkan di bawah sinar matahari dan setelah kering kemudian digiling menjadi tepung.

Tabel 1. Susunan ransum dan kandungan nutrisi ransum penelitian

\begin{tabular}{lccccc}
\hline Bahan Pakan (\%) $^{\text {P0 }}$ & P1 & P2 & P3 & P4 \\
\hline Jagung kuning $^{\text {a }}$ & 54,5 & 55,4 & 55 & 54,8 & 50,7 \\
Dedak $^{\text {a }}$ & 5 & 5 & 5 & 5 & 5 \\
Konsentrat broiler $^{\mathrm{b}}$ & 39,4 & 38 & 36,4 & 34,6 & 36,7 \\
Garam dapur & 0,1 & 0,1 & 0,1 & 0,1 & 0,1 \\
Mineral mixture & 0,5 & 0,5 & 0,5 & 0,5 & 0,5 \\
Top Mix & 0,5 & 0 & 0 & 0 & 0 \\
Tepung Daun Sirsak & 0 & 1 & 3 & 5 & 7 \\
\hline Total & 100 & 100 & 100 & 100 & 100 \\
\hline ME (kkal/kg) & 3003,65 & 3019,77 & 3012,57 & 3006,41 & 2979,93 \\
Protein kasar (\%) & 21,63 & 21,20 & 20,66 & 20,05 & 20,72 \\
Serat kasar (\%) & 4,02 & 4,27 & 4,78 & 5,28 & 5,90 \\
Lemak Kasar (\%) & 4,75 & 4,78 & 4,80 & 4,83 & 4,93 \\
Abu (\%) & 1,56 & 1,66 & 1,84 & 2,02 & 2,13 \\
Ca (\%) & 1,25 & 1,24 & 1,23 & 1,23 & 1,32 \\
P (\%) & 0,80 & 0,78 & 0,76 & 0,75 & 0,77 \\
\hline
\end{tabular}

\section{Ayam, Pakan dan Perlakuan}

Ayam broiler yang digunakan pada penelitian ini adalah ayam broiler dengan strain MBM 202 Lohman. DOC yang baru datang diberi minum dengan air gula merah untuk memulihkan kondisi tubuh ayam akibat stress perjalanan. Sebelum perlakuan dilakukan penimbangan ayam broiler sebagai bobot awal. Selanjutnya sebanyak 160 ekor ayam broiler ditempatkan secara acak kedalam 5 perlakuan dengan 4 ulangan dan setiap ulangan terdiri dari 8 ekor ayam broiler. Ayam broiler diperlihara dalam kandang litter brooder sampai dengan umur 14 hari dan kandang sekat pada umur 15 sampai 35 hari. Untuk mencegah timbulnya penyakit Newcastle Disease (ND) maka vaksinasi ND dilakukan pada umur 4 hari dan 21 hari.

Rancangan yang digunakan pada penelitian ini yaitu Rancangan Acak Lengkap dengan 5 perlakuan dengan 4 ulangan dan setiap ulangan terdiri dari 8 ekor ayam broiler. Perlakuan yang digunakan pada penelitian ini adalah: P0: Penggunaan $0 \%$ daun sirsak fermentasi dalam ransum; P1: Penggunaan 1\% daun sirsak fermentasi dalam ransum; P2: 
Penggunaan 3\% daun sirsak fermentasi dalam ransum; P3: Penggunaan 5\% daun sirsak fermentasi dalam ransum; P4: Penggunaan 7\% daun sirsak fermentasi dalam ransum. Susunan kompoisis pakan percobaan disajikan pada Tabel 1. Pakan dan air minum diberikan ad libitum.

\section{Sampling}

Pada umur 35 hari, 8 ekor broiler betina untuk setiap perlakuan diseleksi dan disembelih. Lemak abdomen, lemak sartorial, lemak leher, lemak gizzard dan lemak proventrikulus diambil dan ditimbang. Fatty liver score. Diukur dengan membandingkan warna hati broiler dengan warna standar dari nilai 1 (coklat tua) sampai dengan nilai 5 (putih kekuningan). Semakin tinggi nilai fatty liver menunjukkan semakin tinggi deposisi lemak dalam hati.

\section{Analisis Data}

Data yang diperoleh dianalisis dengan sidik ragam apabila terdapat perbedaan dilakukan uji lanjut dengan menggunakan Duncan's Multiple Range Test (DMRT) untuk melihat perbedaan antara perlakuan.

\section{HASIL DAN PEMBAHASAN}

Pengaruh pemberian tepung daun fermentasi disajikan pada Tabel 2. Hasil penelitian menunjukkan bahwa penggunaan tepung daun sirsak yang difermentasi dengan Aspergillus niger dalam ransum berpengaruh tidak nyata $(P>0,05)$ terhadap lemak abdominal, lemak sartorial, lemak leher, lemak gizzard, lemak proventrikulus dan fatty liver score.

Tabel 2. Pengaruh pemberian tepung daun sirsak fermentasi terhadap deposisi lemak pada broiler

\begin{tabular}{lllllll}
\hline Variabel & $\mathrm{P} 0$ & $\mathrm{P} 1$ & $\mathrm{P} 2$ & $\mathrm{P} 3$ & $\mathrm{P} 4$ & $\mathrm{P}$ \\
\hline Lemak abdomen, \% & $0,40 \pm 0,20$ & $0,67 \pm 0,24$ & $0,76 \pm 0,17$ & $0,61 \pm 0,20$ & $0,64 \pm 0,23$ & 0,23 \\
Lemak sartorial, \% & $0,23 \pm 0,08$ & $0,35 \pm 0,12$ & $0,35 \pm 0,10$ & $0,26 \pm 0,05$ & $0,34 \pm 0,14$ & 0,36 \\
Lemak leher, \% & $0,02 \pm 0,01$ & $0,03 \pm 0,01$ & $0,02 \pm 0,01$ & $0,02 \pm 0,01$ & $0,03 \pm 0,02$ & 0,46 \\
Lemak gizzard, \% & $0,34 \pm 0,07$ & $0,43 \pm 0,12$ & $0,36 \pm 0,09$ & $0,47 \pm 0,22$ & $0,32 \pm 0,07$ & 0,43 \\
Lemak & $0,08 \pm 0,03$ & $0,07 \pm 0,02$ & $0,07 \pm 0,01$ & $0,08 \pm 0,03$ & $0,06 \pm 0,02$ & 0,84 \\
proventrikulus, \% & $1,88 \pm 0,32$ & $2,06 \pm 0,31$ & $1,88 \pm 0,48$ & $2,31 \pm 0,85$ & $2,31 \pm 0,43$ & 0,59 \\
Fatty liver score & 1,86
\end{tabular}

P0: Pemberian 0\% daun sirsak fermentasi; P1: Pemberian 1\% daun sirsak fermentasi; P2: Pemberian 3\% daun sirsak fermentasi; P3: Pemberian 5\% daun sirsak fermentasi; P4: Pemberian 7\% daun sirsak fermentasi

Hasil skrining fitokimia pada daun sirsak (Annona muricata) ditemukan senyawa metabolit sekunder alkaloid, flavonoid, terpenoid, kumarin dan lakton, antrakuinon, tanin, glikosida, fenol, fitosterol, dan saponin (Tando, 2018). Tidak menurunnya deposisi lemak pada broiler diduga karena kandungan dalam daun sirsak seperti flavonoid, fenol, alkaloid, saponin, fitosterol dan tanin tidak cukup banyak untuk dapat menurunkan deposisi lemak pada broiler. Padahal menurut Li dan Tian (2004) bahwa flavonoid mampu menghambat sintesis asam lemak yang dapat menurunkan deposisi lemak abdomen. Sementara, Kim et al. (2011) alkaloid dapat menurunkan deposisi lemak dengan memperkecil ukuran sel lemak. Subekti (2007) melaporkan bahwa fitosterol dapat menurunkan deposisi lemak dalam karkas dan hati. Salah satu mekanisme perubahan deposisi lemak adalah perubahan ukuran sel lemak. Tugiyanti et al. (2017) melaporkan bahwa pemberian tepung daun sirsak sampai dengan $15 \%$ tidak mampu menurunkan sel lemak pada itik Tegal. Proses fermentasi dengan menggunakan Aspergillus niger diduga juga tidak mampu meningkatkan flavonoid dan senyawa metabolit sekunder lainnya yang mempunyai sifat anti lipid. 
Faktor lain yang dapat mempengaruhi deposisi lemak adalah kadar energi dan protein dalam pakan. Kadar energi pakan yang lebih tinggi akan dapat meningkatkan deposisi lemak, sedangkan kadar protein pakan yang lebih rendah dapat juga meningkatkan deposisi lemak. Hasil perhitungan komposisi zat gizi pakan pada Tabel 1 menunjukkan bahwa kadar energi dan protein relatif sama antar perlakuan. Jadi, penyebab tidak menurunya deposisi lemak abdomen diduga karena tidak cukup kadar senyawa aktif dalam daun sirsak dan kadar energi dan protein pakan yang relatif sama.

Lemak abdomen dalam penelitian ini berkisar antara 0,40\%-0,76\% dengan rata-rata sebesar 0,62\%. Hasil tersebut lebih kecil jika dibandingkan dengan hasil penelitian Fajar et al., (2019) yang melaporkan bahwa lemak abdomen pada broiler umur 35 hari berkisar antara 1,34\%-1,69\% dengan rata-rata $1,58 \%$. Sementara, lemak sartorial dalam penelitian ini berkisar antara 0,26\%-0,35\%. Hasil tersebut lebih kecil jika dibandingkan dengan hasil penelitian Makrup (2019) yang menggunakan tepung daun senduduk (Melastoma malabathrichum L.) fermentasi, yaitu berkisar antara 0,08\%-0,15\%. Hazizan (2007) melaporkan bahwa broiler umur 5 minggu mempunyai kisaran persentase lemak sartorial sebesar 0,35\%-0,44\%, sedangkan Rusydan (2008) melaporkan bahwa lemak sartorial broiler umur 35 hari berkisar antara 0,59\%-0,78\%. Berdasarkan data yang didapatkan oleh penelitian sebelumnya maka dapat disimpulkan bahwa lemak sartorial ayam broiler pada umur yang sama sangat bervariasi. Pada penelitian ini lemak leher berkisar antara 0,02\%-0,03\%. Hasil tersebut relatif sama jika dibandingkan dengan hasil penelitian Makrup (2019). Kadar lemak gizzard pada penelitian ini lebih kecil jika dibandingkan dengan hasil penelitian Faber (2011) yaitu berkisar antara 0,90\%-1,28\%. Kadar lemak proventrikulus pada penelitian ini lebih kecil jika dibandingkan dengan hasil penelitian Dorisandi et al. (2017) yang melaporkan bahwa lemak proventrikulus broiler umur 35 hari berkisar antara 0,17\%0,24\%.

Fatty liver score merupakan nilai yang menunjukkan derajat akumulasi lemak dalam hati. Skor yang lebih tinggi menunjukkan akumulasi lemak yang tinggi di dalam hati. Hati yang memiliki warna coklat kemerahan atau coklat terang adalah warna hati yang normal sedangkan warna hati yang menjadi kuning merupakan indikasi bahwa hati berlemak tinggi (Randall et al., 1986). Menurut McLelland (1990) bahwa apabila hati terjadi keracunan maka warna hati akan berubah menjadi kuning. Berdasarkan skor fatty liver score maka dapat diprediksi bahwa deposisi lemak dalam hati juga tidak menurun akibat pemberian daun sirsak fermentasi.

\section{KESIMPULAN}

Berdasarkan hasil penelitian dapat disimpulkan bahwa penggunaan tepung daun sirsak (Annona muricata L.) yang difermentasi dengan Aspergillus niger sampai dengan 7\% tidak menurunkan deposisi lemak ayam broiler.

\section{DAFTAR PUSTAKA}

Aranaz, P., D. Navarro-Herrera, M. Zabala, A. Romo-Hualde, M. Lopez-Yoldi, J. L. Vismanos, F. Milagro dan C. J. GonzalesNavarro. 2020. Phenolic compounds reduce the fat content in Caenorhabditis elegans by affecting lipogenesis, lipolysis, and different stress responses. Pharceuticals (Basel), 13 (11): 355

Bao, L., L. Hu, Y. Zhang dan Y. Wang. 2016. Hypolipidemic effects of flavonoids extracted from Lomatogonium rotatum. Experimental and Therapeutic Medicine, 11 (4): 1417-1424.

Dorisandi, M., L. Saputro, S.H. Jatmiko dan Y. Fenita. 2017. Pengaruh pemberian fermentasi tepung kulit pisang jantan dengan menggunakan neurospora crassa terhadap deposisi lemak ayam 
broiler. Jurnal Sain Peternakan Indonesia, 12(3): 325-334.

Faber, J. 2011. Penggunaan ekstrak akar alangalang (Imperata cyilindica) untuk menurunkan lemak pada broiler. Skripsi. Jurusan Peternakan. Universitas Bengkulu. Bengkulu

Fajar. M. Z. A., O. Induk dan R. Yusup. 2019. Pemanfaatan daun sirsak (Annona muricata I.) sebagai feed additive terhadap konsumsi pakan, PBB, FCR dan lemak abdominal pada ayam broiler. Jurnal Peternakan Lingkungan Tropis, 2 (1):43-9.

Hazizan, H. 2007. Pengaruh pemberian tepung daun sukun (Artocarpus communis) terhadap akumulasi lemak pada broiler. Skripsi. Jurusan Peternakan. Universitas Bengkulu.

Hidanah, S., Setyono, H. Nazar, D.S. Lokapirnasari dan W.P. dan Pratisto. 2009. Potensi limbah kulit ari kedelai yang diproses secara kimiawi dan fermentasi untuk peningkatan performans ayam pedaging. Fakultas Kedokteran Hewan Universitas Airlangga. Surabaya.

Kim, K. J., M. S. Lee, K. Jo, dan J. K. Hwang . 2011. Piperidine alkaloids from Piper retrofractum Vahl. protect against high-fat diet-induced obesity by regulating lipid metabolism and activating AMP-activated protein kinase. Biochem. Biophys. Res. Com., 22: 219-225.

Li, B. H. dan W. X. Tian. 2004. Inbitory effects of flavonoid on animal fatty acid synthate. J. Biochem. 135: 85-91.

Mahendra, Y. A. 2016. Pengaruh jenis mikroorganisme dan lama fermentasi terhadap residu protein produk fermentasi hasil samping udang. Skripsi. Universitas Lampung. Bandar Lampung.

Mairizal. 2009. Pengaruh pemberian kulit biji kedelai hasil fermentasi dengan Aspergillus niger sebagai pengganti jagung dan bungkil kedelai dalam ransum terhadap retensi bahan kering, bahan organik, dan serat kasar pada ayam pedaging. Jurnal IImiah Ilmu-Ilmu Peternakan 12(1) : 35-40.
Mait, Y.S., J. E. G. Rompis, B. Tulung, J. Laihad dan J. J. M. R. Londok. 2019. Pengaruh pembatasan pakan dan sumber serat kasar berbeda terhadap bobot hidup, bobot karkas, dan bobot potong komersial karkas ayam broiler starin lohman. Zootec., 39 (1) : 134-145.

Makrup, R. 2019. Pengaruh penggunaan tepung daun senduduk (melastoma malabathricum I.) Fermentasi dalam ransum terhadap deposisi lemak broiler. skripsi. Universitas Bengkulu.

Maryanti, Y.H., Pristianti dan P. Ruliawati. 2010. Produksi crude lipase dari Aspergillus niger pada substratongok menggunakan metode fermentasi fase padat. Seminar Rekayasa Kimia dan Proses. Universitas Diponegoro, Semarang: 4-5 Agustus 2010

McLelland, J. 1990. Colour Atlas of Avian Anotomy. Wolfe Publishing Ltd. London.

Murwandhono, E., I. Bachari dan D. Situmorang. 2006. Uji nilai nutrisi kulit ubi kayu yang difermentasi dengan Aspergillus niger. Jurnal Agribisnis Peternakan, 2 (3).91-95.

Randall, Cj., K. S. Kirkpatrick, D. B. Pearson. 1986. Liver abnomality in broiler. Canada J. Vet. Res., 119 (23): 576-576.

Rasyaf, M. 2002. Beternak Ayam Pedaging. Penebar Swadaya. Jakarta.

Rusydan, M. 2008. Pengaruh penggunaan tepung akar alang-alang (Imperata cyilindica) terhadap penimbunan lemak pada broiler. Skripsi. Jurusan Peternakan. Universitas Bengkulu. Bengkulu.

Subekti, S. 2007. Komponen sterol dalam ekstrak daun katuk (Sauropus androgynus L. Merr) dan hubungannya dengan sistem reproduksi puyuh. Disertasi, IPB, Bogir.

Suranto, A. 2011. Dahsyatnya Sirsak Tumpas Penyakit. Pustaka Bunda, Jakarta, pp. 5456.

Tandu, E. 2018. Review: Potensi senyawa metabolit sekunder dalam daun sirsak (Annona murricata) dan srikaya (Annona squamosa) sebagai pestisida nabati untuk 
pengendalian hama dan penyakit pada tanaman. Jurnal Biotropika, 6 (1): 21-27.

Tugiyanti, E., N. Mawarti, Rosidi, I. Harisulistyawan. 2017. The effect of soursop (Announa muricata L.) leaves powder on diameter of muscle fiber, lipid cells, body weight gain and carcass percentage of Tegal duck. Anim. Prod., 19 (1): 47-54.

Yusak, Y. 2004. Pengaruh suhu dan pH bufer asetat terhadap hidrolisa CMC oleh enzim selulase dari ekstrak Aspergillus niger dalam media campur onggok dan dedak. Jurnal Sains Kimia, 8(2): 35- 37. 